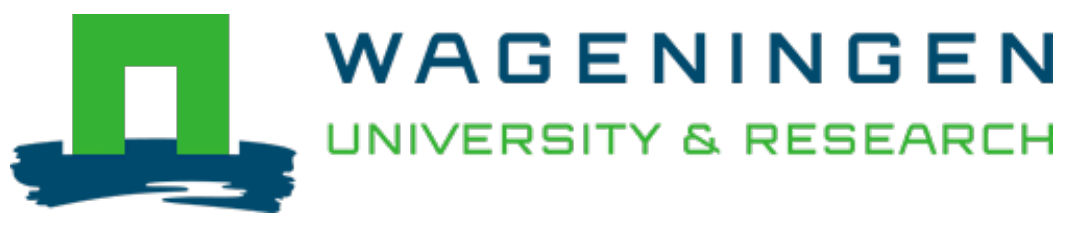

\title{
Evaluation of the Simultaneous Effects of Processing Parameters on the Iron and Zinc Solubility of Infant Sorghum Porridge by Response Surface Methodology
}

\author{
Journal of Agricultural and Food Chemistry \\ Kayodé, A.P.P.; Nout, M.J.R.; Bakker, E.J.; Boekel, M.A.J.S. \\ https://doi.org/10.1021/jf0530493
}

This publication is made publicly available in the institutional repository of Wageningen University and Research, under the terms of article $25 \mathrm{fa}$ of the Dutch Copyright Act, also known as the Amendment Taverne. This has been done with explicit consent by the author.

Article 25 fa states that the author of a short scientific work funded either wholly or partially by Dutch public funds is entitled to make that work publicly available for no consideration following a reasonable period of time after the work was first published, provided that clear reference is made to the source of the first publication of the work.

This publication is distributed under The Association of Universities in the Netherlands (VSNU) 'Article $25 \mathrm{fa}$ implementation' project. In this project research outputs of researchers employed by Dutch Universities that comply with the legal requirements of Article $25 \mathrm{fa}$ of the Dutch Copyright Act are distributed online and free of cost or other barriers in institutional repositories. Research outputs are distributed six months after their first online publication in the original published version and with proper attribution to the source of the original publication.

You are permitted to download and use the publication for personal purposes. All rights remain with the author(s) and / or copyright owner(s) of this work. Any use of the publication or parts of it other than authorised under article $25 \mathrm{fa}$ of the Dutch Copyright act is prohibited. Wageningen University \& Research and the author(s) of this publication shall not be held responsible or liable for any damages resulting from your (re)use of this publication.

For questions regarding the public availability of this publication please contact openscience.library@wur.nl 


\title{
Evaluation of the Simultaneous Effects of Processing Parameters on the Iron and Zinc Solubility of Infant Sorghum Porridge by Response Surface Methodology
}

\author{
A. P. Polycarpe Kayodé,${ }^{\dagger}$ Martinus J. R. Nout, ${ }^{*}{ }^{\ddagger}$ Evert J. Bakker,${ }^{\S}$ And \\ Martinus A. J. S. VAN Boekel"
}

\begin{abstract}
Département de Nutrition et Sciences Alimentaires, Faculté des Sciences Agronomiques, Université d'Abomey-Calavi, 01 BP 526 Cotonou, Bénin, Laboratory of Food Microbiology and Product Design and Quality Management Group, Wageningen University, P.O. Box 8129, 6700 EV Wageningen, The Netherlands, and Biometris, Wageningen University, P.O. Box 100,
\end{abstract} 6700 AC Wageningen, The Netherlands

\begin{abstract}
The purpose of this study was to improve the micronutrient quality of indigenous African infant flour using traditional techniques available in the region. Response surface methodology was used to study the effect of duration of soaking, germination, and fermentation on phytate and phenolic compounds (PC), $\mathrm{pH}$, viscosity, and the in vitro solubility (IVS) of iron and zinc in infant sorghum flour. The phytate and the PC concentrations of the flour were significantly modified as a result of the duration of germination and fermentation and their mutual interaction. These modifications were accompanied by a significant increase in \% IVS Zn after $24 \mathrm{~h}$ of sprouting. Except for the interaction of soaking and fermentation, none of the processing parameters exerted a significant effect on the \% IVS Fe. The viscosity of the porridge prepared with the flour decreased significantly with the duration of germination, making it possible to produce a porridge with high energy and nutrient density. The use of germination in combination with fermentation is recommended in the processing of cereals for infant feeding in developing countries.
\end{abstract}

KEYWORDS: Response surface methodology; processing; Fe; Zn; in vitro solubility, phytate; phenolics

\section{INTRODUCTION}

Iron $(\mathrm{Fe})$ and zinc $(\mathrm{Zn})$ are essential trace elements in human nutrition. Fe is a core element in the synthesis of hemoglobin and myoglobin. It contributes to the formation of heme enzymes and other Fe-containing enzymes that are important for energy production, immune defense, and thyroid function. Most of the $\mathrm{Zn}$ in the human body is in the bones and skeletal muscles. $\mathrm{Zn}$ contributes in the activities of over 300 enzymes and participates in gene expression and in the synthesis and degradation of carbohydrates, lipids, proteins, and nucleic acids. Its contribution to the stabilization of the structure of membrane and cellular components has been documented $(1,2)$. Moderate $\mathrm{Zn}$ deficiencies in infants and children are associated with reduced growth and development, impaired immunity, and increased morbidity and mortality from infections as was demonstrated in metaanalyses and controlled trials $(3,4)$.

* To whom correspondence should be addressed. Fax: +31 317484978 E-mail: rob.nout@wur.nl.

† Université d'Abomey-Calavi.

$\doteqdot$ Laboratory of Food Microbiology, Wageningen University.

$\S$ Biometris, Wageningen University. sity.

" Product Design and Quality Management Group, Wageningen Univer-
In many developing countries, cereal porridges are introduced in infant feeding before the age of 4 months and this practice is associated with malnutrition problems. Thirty-two percent of children under 5 years old suffer from being underweight and $39 \%$ from stunting in developing countries. The occurrence of infant malnutrition varies according to region, with the highest prevalence in South Asia and sub-Saharan Africa where 53 and $41 \%$ were reportedly stunted, respectively (5). Whereas these data appear high as compared with more recent Unicef data, in Cotonou, Benin, nevertheless, $76 \%$ of the children $3-5$ years of age were found to be anemic and 58\% were stunted (6). In Burkina-Faso, $70 \%$ of the under fives and $40 \%$ of pregnant women were reported to be anemic (7).

Traditional complementary foods in sub-Saharan Africa are thin porridges usually prepared from cereal grains such as sorghum, millet, or maize. These porridges are designated under various names depending on region and location. They are known as koko in Benin and Ghana, ogi in Nigeria, uji in Kenya, and magai in Tanzania (8). Among the cereals used to produce infant porridges, sorghum is of particular importance. In certain regions, the sorghum porridge is believed to be the best complementary food (9). In addition, sorghum as a crop has the comparative advantage of being resistant to harsh environ- 
mental conditions and the crop is cultivated by many subsistence farmers for home consumption (10-12).

Basically, the processing of infant porridges in many areas of West Africa involves soaking, grinding, occasionally fermentation, and cooking. Fermented products are acidic $(\mathrm{pH} 3.5-$ 4), microbiologically safe, and easily digestible (13). However, the content and bioavailability of minerals of cereal porridges are relatively low due to the presence of antinutritional factors such as phytate, which forms insoluble complexes with essential minerals such as $\mathrm{Fe}$ and $\mathrm{Zn}$ at physiological $\mathrm{pH}$ levels (14). Phytate may be partially responsible for the widespread mineral deficiencies observed in populations that subsist largely on sorghum and other cereals (15). Furthermore, it has been suggested that phytate may diminish solubility, digestibility, and activity of proteins such as digesting enzymes (16). Therefore, processes that decrease the phytate content in foods are highly desirable. Another problem with the cereal-based porridges is their bulkiness, which reduces their energy and nutrient density.

Germination of cereal grains has the distinct advantage of reducing the bulkiness of the derived gruel because of the production of endogenous grain amylases, particularly $\alpha$-amylase. In addition, during germination, endogenous phytase may be activated leading to phytate degradation (17). Several studies demonstrated that germination facilitates the hydrolysis of condensed phenolic compounds (PCs) $(18,19)$, which also exhibit chelating properties for minerals such as Fe (20). The introduction of germination in the preparation of infant food in developing countries is desirable for its nutritional benefit and is culturally feasible; germination is a traditional technique widely used in Africa for the production of local malted foods and beverages.

To improve the nutritional and the functional properties of indigenous infant porridges, modifications may be incorporated in the traditional processing method by introducing the germination step. More specifically, the objective was to evaluate the effect of three process variables, duration of soaking, germination, and fermentation, on the in vitro solubility (IVS) of Fe and $\mathrm{Zn}$, levels of phenolics and phytate, and viscosity of resulting porridges. It is quite likely that the effect of one process value depends on the value of another, so interactions between factors may be important. Such interactions will not be detected using the one-factor-at-a-time approach (21), so we decided to use a design methodology that is able to detect such interactions. Therefore, response surface methodology (RSM) was used applying a central composite design. Central composite designs are the basis for RSM and are used to estimate parameters of a full second-degree model. Such a quadratic model is usually sufficient for accuracy in product and process design (21).

\section{MATERIALS AND METHODS}

Plant Material. Sorghum [Sorghum bicolor (L.) Moench] variety Mahi swan, with high food preferences by housewives, was provided by a farmer in the Banikoara region and cultivated at the Agricultural Research Centre located at Ina in Northern Benin. The seed was grown on a tropical ferruginous type soil in 2003 under the natural season of the Guinea Savannah climate of West Africa. The annual rainfall in the regions varies from 985 to $1473 \mathrm{~mm}$ with an average value of 1237 $\mathrm{mm}$ (22).

Experimental Design. RSM is a statistical method that uses quantitative data derived from an appropriate experimental design with quantitative factors to estimate the relationship between a response and the factors in order to optimize processes or products (23). In this study, an orthogonal rotatable central composite design (24) for $K=3$ factors was used to estimate the simultaneous effect of three process variables on antinutritional factors, $\mathrm{pH}$, porridge viscosity, and $\mathrm{Fe}$ and $\mathrm{Zn}$
Table 1. Design Matrix and Variable Combinations

\begin{tabular}{|c|c|c|c|c|c|c|}
\hline \multirow[b]{2}{*}{$\begin{array}{l}\text { treatment } \\
\text { code }\end{array}$} & \multicolumn{3}{|c|}{ level codes } & \multicolumn{3}{|c|}{ variable level } \\
\hline & soaking & germination & fermentation & $\begin{array}{l}\text { soaking } \\
\text { (h) }\end{array}$ & $\begin{array}{l}\text { germination } \\
\text { (h) }\end{array}$ & $\begin{array}{l}\text { fermentation } \\
\text { (h) }\end{array}$ \\
\hline 1 & 0 & 0 & 0 & 10.0 & 36.0 & 36.0 \\
\hline 2 & 0 & 0 & 0 & 10.0 & 36.0 & 36.0 \\
\hline 3 & 0 & 0 & 0 & 10.0 & 36.0 & 36.0 \\
\hline 4 & 0 & 0 & 0 & 10.0 & 36.0 & 36.0 \\
\hline 5 & 0 & 0 & 0 & 10.0 & 36.0 & 36.0 \\
\hline 6 & 0 & 0 & 0 & 10.0 & 36.0 & 36.0 \\
\hline 7 & 0 & 0 & 0 & 10.0 & 36.0 & 36.0 \\
\hline 8 & 0 & 0 & 0 & 10.0 & 36.0 & 36.0 \\
\hline 9 & 0 & 0 & 0 & 10.0 & 36.0 & 36.0 \\
\hline 10 & -1 & -1 & -1 & 7.82 & 14.59 & 14.59 \\
\hline 11 & -1 & 1 & -1 & 7.82 & 57.4 & 14.59 \\
\hline 12 & -1 & -1 & 1 & 7.82 & 14.59 & 57.4 \\
\hline 13 & 1 & -1 & -1 & 12.18 & 14.59 & 14.59 \\
\hline 14 & 1 & 1 & 1 & 12.18 & 57.4 & 57.4 \\
\hline 15 & -1 & 1 & 1 & 7.82 & 57.4 & 57.4 \\
\hline 16 & 1 & -1 & 1 & 12.18 & 14.59 & 57.4 \\
\hline 17 & 1 & 1 & -1 & 12.18 & 57.4 & 14.59 \\
\hline 18 & -1.6818 & 0 & 0 & 6.0 & 36.0 & 36.0 \\
\hline 19 & 0 & -1.6818 & 0 & 10.0 & 0.0 & 36.0 \\
\hline 20 & 0 & 0 & -1.6818 & 10.0 & 36.0 & 0.0 \\
\hline 21 & 1.6818 & 0 & 0 & 14 & 36.0 & 36.0 \\
\hline 22 & 0 & 1.6818 & 0 & 10.0 & 72.0 & 36.0 \\
\hline 23 & 0 & 0 & 1.6818 & 10.0 & 36.0 & 72.0 \\
\hline 24 & 0 & 0 & 1 & 10.0 & 36.0 & 57.4 \\
\hline 25 & 0 & 0 & -1 & 10.0 & 36.0 & 14.59 \\
\hline 26 & 0 & 1 & 0 & 10.0 & 57.4 & 36.0 \\
\hline 27 & 0 & -1 & 0 & 10.0 & 14.59 & 36.0 \\
\hline 28 & 1 & 0 & 0 & 12.18 & 36.0 & 36.0 \\
\hline 29 & -1 & 0 & 0 & 7.82 & 36.0 & 36.0 \\
\hline
\end{tabular}

solubility in a quadratic function. The variables (factors) were the duration of soaking $(6-14 \mathrm{~h})$, duration of germination $(0-72 \mathrm{~h})$, and duration of fermentation $(0-72 \mathrm{~h})$. The responses were $\mathrm{pH}$, titratable acidity, phytate, phenolics, final apparent porridge viscosity, and $\mathrm{Fe}$ and $\mathrm{Zn}$ solubilities. The design generated 23 observations, which were distributed as follows: eight kernel points, six star points, and nine replications at the central point. Six additional between and extreme points were added to increase the accuracy of the observations. The design matrix and variable combinations are presented in Table $\mathbf{1 .}$

Experimental Processing. Two $100 \mathrm{~g}$ aliquots of cleaned sorghum grains were soaked in distilled water $(1 / 5, \mathrm{w} / \mathrm{v})$ during the period as predefined in the experimental design (Table 1). Subsequently, the grains were drained for $5 \mathrm{~min}$ and laid on a polythene sheet with cover and allowed to germinate during the predefined period. The grains were sprayed with distilled water twice daily. At the end of germination, the sprouted grains were dried at $50{ }^{\circ} \mathrm{C}$ in an oven for $16 \mathrm{~h}$. The rootlets were removed, and the grains were ground to flour using a Retsch mill (type ZM 1, Retsch, Haan, Germany) fitted with a $0.5 \mathrm{~mm}$ screen. For the fermentation, the flour was mixed with distilled water $(45 \% \mathrm{w} / \mathrm{w})$, kneaded into dough, and allowed to ferment in a plastic bucket with a lid. The fermented dough was dried and ground to flour as described above. Samples were packed in polythene bags and stored at $-20^{\circ} \mathrm{C}$ until analysis.

In Vitro Digestion. Step 1-the enzymatic degradation-of the in vitro digestion method described by Kiers et al. (25) was used. Duplicate dry samples of flour $(5 \mathrm{~g})$ were suspended in $30 \mathrm{~mL}$ of distilled water and digested under simulated gastrointestinal conditions, subsequently using $\alpha$-amylase solution (Sigma A-1031), stomach medium consisting of lipase (Amano Pharmaceuticals, Rhizopus F-AP15) and pepsin (Sigma P-6887), and pancreatic solution consisting of pancreatin (Sigma P-1750) and bile (Sigma B-3883). After digestion, the suspension was centrifuged at $3600 \mathrm{~g}$ for $15 \mathrm{~min}$ at $4{ }^{\circ} \mathrm{C}$. The supernatant was decanted, and the pellet was washed twice in $20 \mathrm{~mL}$ of distilled water and centrifuged. The supernatants were pooled and filtered through a 0.45 $\mu \mathrm{m}$ pore filter. A blank was included consisting of $30 \mathrm{~mL}$ of distilled water digested and filtered as described above. Both filtered supernatants from sample and blank were analyzed for $\mathrm{Fe}$ and $\mathrm{Zn}$. Samples were corrected for added reagents and water by subtracting $\mathrm{Fe}$ and $\mathrm{Zn}$ contents of blank from that of supernatants from samples. The amounts 
of $\mathrm{Fe}$ and $\mathrm{Zn}$ (expressed as $\mathrm{mg} / \mathrm{kg}$ dry matter of digested sample) in supernatant were regarded as dissolved minerals. The percentage of dissolved mineral was calculated as: IVS $(\%)=(\mathrm{Fe}$ or $\mathrm{Zn}$ in supernatant $-\mathrm{Fe}$ or $\mathrm{Zn}$ in blank)/(Fe or $\mathrm{Zn}$ in undigested sample) $\times 100$.

Measurement of Viscosity. The final apparent porridge viscosity, i.e., the viscosity after cooling the hot porridge to $50^{\circ} \mathrm{C}$, which roughly corresponds to the temperature at which porridges are appreciated by consumers, was measured using a Rapid Visco Analyzer (RVA, Newport Scientific, Narrabeen, Australia) following the method of Mestres et al. (26). The apparent viscosity was expressed in arbitrary RVA units, one unit approximating $0.012 \mathrm{~Pa}$ s.

Iron and Zinc Determination. Approximately $0.4 \mathrm{~g}$ of flour was digested using hydrofluoric acid $(40 \%)$ and concentrated nitric acid $(65 \% \mathrm{w} / \mathrm{w})(27)$. Next, the concentrations of $\mathrm{Fe}$ and $\mathrm{Zn}$ were analyzed by an inductively coupled plasma -optical emission spectrometer (Elan 6000 , Perkin-Elmer, United States) (28). Samples from in vitro digestion were collected in tubes $(10 \mathrm{~mL})$, and $0.15 \mathrm{~mL}$ of concentrated nitric acid $\left(\mathrm{HNO}_{3} 65 \%\right)$ was added to preserve them. These samples were analyzed by the inductively coupled plasma-mass spectrometer (Elan 6000 , Perkin-Elmer). Analyses were performed in duplicate.

Phytate Determination. Ten milligrams of grain flour was extracted with $1 \mathrm{~mL}$ of $0.5 \mathrm{~N} \mathrm{HCl}$ containing $50 \mathrm{mg} / \mathrm{L}$ cis-aconitate (internal standard) (29). The mixture was boiled in a water bath at $100{ }^{\circ} \mathrm{C}$ for $15 \mathrm{~min}$ and then centrifuged at $14000 \mathrm{~g}$ for $10 \mathrm{~min}$. The supernatant was diluted $5 \times$ in Millipore water and analyzed using high-performance liquid chromatography (HPLC) (Dionex DX300, ICS2500 system, detector range of $10 \mu \mathrm{S}$ ) using the column AS11 (ATC column + guard column). Detection was with suppressed conductivity, and the suppression was done with water at a flow rate of $5 \mathrm{~mL} / \mathrm{min}$. The eluent and the elution times used are as follows: $0-5 \mathrm{~min}, 5 \mathrm{mM} \mathrm{NaOH}$; 5-15 min, 5-100 mM NaOH; 15-20 min, $500 \mathrm{mM} \mathrm{NaOH}$; and 20$35 \mathrm{~min}, 5 \mathrm{mM} \mathrm{NaOH}$. A standard solution was prepared in Millipore water, containing $5.0 \mathrm{mg} / \mathrm{L} \mathrm{NaNO}_{3}$ (Merck p.a.), $5.0 \mathrm{mg} / \mathrm{L} \mathrm{Na} \mathrm{SO}_{4}$ (Merck p.a.), $5.0 \mathrm{mg} / \mathrm{L}$ oxalic acid $\cdot 2 \mathrm{H}_{2} \mathrm{O}$ (Merck p.a.), $10.0 \mathrm{mg} / \mathrm{L} \mathrm{Na}_{2-}$ $\mathrm{HPO}_{4} \cdot 2 \mathrm{H}_{2} \mathrm{O}$ (Merck 6346 p.a.), $10 \mathrm{mg} / \mathrm{L}$ citric acid, $\mathrm{H}_{2} \mathrm{O}$ (Merck K23524044 719 p.a.), $5.0 \mathrm{mg} / \mathrm{L}$ cis-aconitate (Aldrich 27194-2), and $10 \mathrm{mg} / \mathrm{L} \mathrm{IP} 6 \cdot \mathrm{Na}_{12}$ (Sigma P3168 lot 102K0053). Analyses were performed in triplicate.

Total Phenolics Determination. Total PCs were extracted from 50 $\mathrm{mg}$ of flour in $1.5 \mathrm{~mL}$ of $\mathrm{HCl} /$ methanol $(1 \% \mathrm{v} / \mathrm{v})$ for $1 \mathrm{~h}$ under continuous stirring at room temperature. The mixture was centrifuged at $5000 \mathrm{~g}$ for $10 \mathrm{~min}$, and the supernatant was removed. The pellet was re-extracted as described above, and the supernatants were pooled (30). PCs were measured following the method of ref 31 and were modified as follows. To $300 \mu \mathrm{L}$ of extract, $4.2 \mathrm{~mL}$ of distilled water, $0.75 \mathrm{~mL}$ of Folin-Ciocalteu's reagent (Merck, Germany), and $0.75 \mathrm{~mL}$ of sodium carbonate solution $(20 \% \mathrm{w} / \mathrm{v})$ were added. After incubation for $30 \mathrm{~min}$, the optical density was measured at $760 \mathrm{~nm}$ using a spectrophotometer (Shimadzu UV 240, Kyoto, Japan). Blanks were also prepared in which Folin-Ciocalteu's reagent was replaced by water to correct for interfering compounds. Gallic acid (Acros Organics, NJ) was used as the standard, and the results were expressed as gallic acid equivalent per $\mathrm{g}$ of sample dry matter. Blanks were always freshly prepared.

Statistical Analysis. Data were analyzed using the statistical program SPSS 11.0. A second-order polynomial model was proposed to establish the relationship between the responses $(Y)$ and the variables $(X)$ as follows:

$$
Y=b_{0}+\sum_{1}^{3} b_{i} X_{i}+\sum_{1}^{3} b_{i i} X_{i}^{2}+\sum_{i=1}^{2} \sum_{j=i+1}^{3} b_{i j} X_{i} X_{j}
$$

in which $b_{0}$ is a constant, $b_{i}$ is a linear effect coefficient, $b_{i i}$ is a quadratic effect coefficient, $b_{i j}$ is an interaction effect coefficient, and $X_{i}$ is an independent variable $(i, j=1,2,3)$, given as deviation from its mean value. In this way, $b_{0}$ can be interpreted as the estimated value of $Y$ at the central point. The fitted polynomial equations were expressed in a three-dimensional response surface in which the response is presented on the vertical axis and the two factors are at the two horizontal perpendicular axes.
Table 2. Response for Phytate, Total Phenolics, IVS Zn and Fe, Final Apparent Viscosity, $\mathrm{pH}$, and Titratable Acidity ${ }^{a}$

\begin{tabular}{|c|c|c|c|c|c|c|c|}
\hline \multirow[b]{2}{*}{$\begin{array}{l}\text { treatment } \\
\text { code }\end{array}$} & \multirow[b]{2}{*}{$\begin{array}{l}\text { IP6 } \\
(\%)\end{array}$} & \multirow[b]{2}{*}{$\begin{array}{l}\mathrm{PC} \\
(\%)\end{array}$} & \multicolumn{2}{|c|}{ IVS } & \multirow[b]{2}{*}{$\begin{array}{c}\text { V50 } \\
\text { (RVA unit) }\end{array}$} & \multirow[b]{2}{*}{$\mathrm{pH}$} & \multirow[b]{2}{*}{$\begin{array}{l}\text { titratable acidity } \\
\text { (\% lactic acid) }\end{array}$} \\
\hline & & & $\begin{array}{l}\mathrm{Zn} \\
(\%)\end{array}$ & $\begin{array}{l}\mathrm{Fe} \\
(\%)\end{array}$ & & & \\
\hline 1 & 0.29 & 0.38 & 23.2 & 9.4 & 114.6 & 4.1 & 2.20 \\
\hline 2 & 0.22 & 0.47 & 25.4 & 17.4 & 108.2 & 4.1 & 2.24 \\
\hline 3 & 0.22 & 0.41 & 26.0 & 16.4 & 111.9 & 4.2 & 2.15 \\
\hline 4 & 0.25 & 0.5 & 25.4 & 17.5 & 117.3 & 4.1 & 2.25 \\
\hline 5 & 0.25 & 0.44 & 19.6 & 13.2 & 90.8 & 4.0 & 2.25 \\
\hline 6 & 0.24 & 0.43 & 26.8 & 9.8 & 102.1 & 4.1 & 2.20 \\
\hline 7 & 0.32 & 0.4 & 26.4 & 6.6 & 100.4 & 4.1 & 2.13 \\
\hline 8 & 0.26 & 0.46 & 19.8 & 16.7 & 114.1 & 4.1 & 2.20 \\
\hline 9 & 0.17 & 0.41 & 27.0 & 9.5 & 119.2 & 3.8 & 2.42 \\
\hline 10 & 0.24 & 0.26 & 22.4 & 7.5 & 110.2 & 4.5 & 1.68 \\
\hline 11 & 0.09 & 0.36 & 26.7 & 9.3 & 4.1 & 4.4 & 2.09 \\
\hline 12 & 0.28 & 0.29 & 21.9 & 14.8 & 112.4 & 4.2 & 2.21 \\
\hline 13 & 0.68 & 0.29 & 22.4 & 17.8 & 142.7 & 4.3 & 1.92 \\
\hline 14 & 0.27 & 0.46 & 27.3 & 5.6 & 5.2 & 4.2 & 2.47 \\
\hline 15 & 0.11 & 0.43 & 35.2 & 13.8 & 7.5 & 4.2 & 2.32 \\
\hline 16 & 0.02 & 0.41 & 30.3 & 5.7 & 126.3 & 4.2 & 2.35 \\
\hline 17 & 0.21 & 0.39 & 34.1 & 16.8 & 5.0 & 4.5 & 1.83 \\
\hline 18 & 0.27 & 0.41 & 22.3 & 16.1 & 80.1 & 4.1 & 2.17 \\
\hline 19 & 0.15 & 0.37 & 29.1 & 24.6 & 127.1 & 4.4 & 1.76 \\
\hline 20 & 0.56 & 0.35 & 28.6 & 22.3 & 109.8 & 5.9 & 0.61 \\
\hline 21 & 0.17 & 0.37 & 27.6 & 15.7 & 105.9 & 4.1 & 2.35 \\
\hline 22 & 0.02 & 0.45 & 38.1 & 11.3 & 3.7 & 3.8 & 2.47 \\
\hline 23 & 0.19 & 0.41 & 25.5 & 15.0 & 89.1 & 4.1 & 2.38 \\
\hline 24 & 0.14 & 0.4 & 30.8 & 12.6 & 90.7 & 4.1 & 2.39 \\
\hline 25 & 0.16 & 0.39 & 24.3 & 11.8 & 29.2 & 4.3 & 1.86 \\
\hline 26 & 0.18 & 0.44 & 32.3 & 11.0 & 2.7 & 4.4 & 2.07 \\
\hline 27 & 0.28 & 0.39 & 19.4 & 6.5 & 114 & 4.0 & 2.25 \\
\hline 28 & 0.31 & 0.38 & 27.3 & 13.4 & 133.0 & 4.2 & 2.08 \\
\hline 29 & 0.31 & 0.37 & 23.1 & 17.5 & 126.2 & 4.3 & 1.94 \\
\hline
\end{tabular}

${ }^{a}$ IP6, myoinositol hexaphosphate; V50, final apparent viscosity at $50^{\circ} \mathrm{C}$.

\section{RESULTS AND DISCUSSION}

Impact of Processing Parameters on pH and Viscosity of Porridge. The response values for the different treatments are presented in Table 2 . The polynomial equation was fitted to the experimental data using the SPSS program, and the linear regression coefficients estimates are presented in Table $\mathbf{3}$. The sourness is an important quality criterion for the acceptability of fermented sorghum gruel (9). The $\mathrm{pH}$ is a good indicator of the sourness of a food product. The values of $\mathrm{pH}$ for different treatments ranged between 3.8 and 5.9. As could be expected, the $\mathrm{pH}$ and the titratable acidity of the produced flours were affected only by the fermentation period (Table 3 ). The linear and the quadric terms of the fermentation were significant coefficients in the model. The $\mathrm{pH}$ of the fermenting dough decreased significantly to reach its lowest values of 3.8-4.0 after $36 \mathrm{~h}$ of fermentation. Clearly, most of the changes in the $\mathrm{pH}$ of the dough took place during the first $20 \mathrm{~h}$ of fermentation (Figure 1a). It has been demonstrated that at $\mathrm{pH}<4.0$ in food, the growth of diarrhea causing pathogens is inhibited $(13,32)$. Consequently, it can be argued that the flours obtained after 36 $\mathrm{h}$ of fermentation time in this study are inherently safe from a microbiological point of view.

The viscosity of the porridge made with the processed flour was significantly affected by the germination period (Table 3 ). The linear and the quadratic terms were found to be highly significant. From Figure 1b, it is clear that germination time had a decreasing effect on the porridge viscosity whereas the fermentation time played a minor role. Increasing the time of germination resulted in lower porridge viscosity, reaching the lowest values (2.7-7.5 RVA units) after $57 \mathrm{~h}$ of germination. We assume that the decrease of porridge viscosity is due to 
Table 3. Coefficients of the Variables in the Model and Their Corresponding $R^{2}$

\begin{tabular}{|c|c|c|c|c|c|c|c|}
\hline \multirow[b]{2}{*}{ coefficient $^{a}$} & \multirow[b]{2}{*}{ IP6 ${ }^{e}$} & \multirow[b]{2}{*}{ PC } & \multirow[b]{2}{*}{$\mathrm{pH}$} & \multirow{2}{*}{$\begin{array}{l}\text { titratable } \\
\text { acidity }\end{array}$} & \multirow{2}{*}{$\begin{array}{c}\text { final apparent } \\
\text { viscosity }\end{array}$} & \multicolumn{2}{|c|}{$\%$ IVS } \\
\hline & & & & & & $\mathrm{Zn}$ & $\mathrm{Fe}$ \\
\hline$b_{0}$ (constant) & 0.244 & 0.427 & 4.092 & 2.203 & 104.494 & 24.607 & 12.602 \\
\hline$S$ & 0.008 & 0.004 & -0.007 & 0.020 & 2.717 & 0.598 & -0.119 \\
\hline G & $-0.003^{b}$ & $0.002^{d}$ & -0.002 & 0.005 & $-2.353^{d}$ & $0.162^{d}$ & -0.054 \\
\hline$F$ & $-0.004^{c}$ & $0.001^{b}$ & $-0.013^{d}$ & $0.016^{d}$ & 0.048 & 0.032 & -0.069 \\
\hline$S^{2}$ & 0.000 & $-0.004^{b}$ & -0.000 & 0.005 & -0.703 & -0.010 & 0.071 \\
\hline$G^{2}$ & 0.000 & -0.00002608 & -0.00001385 & 0.000003496 & $-0.045^{c}$ & $0.006^{c}$ & 0.000 \\
\hline$F^{2}$ & 0.00007424 & $-0.00005151^{b}$ & $0.001^{d}$ & $0.000^{d}$ & -0.021 & 0.002 & 0.002 \\
\hline$S G$ & 0.000 & 0.000 & 0.001 & -0.001 & -0.128 & -0.024 & -0.005 \\
\hline$S F$ & $-0.002^{b}$ & 0.000 & 0.000 & 0.001 & -0.058 & -0.018 & $-0.094^{b}$ \\
\hline GF & $0.000^{b}$ & -0.000002740 & -0.00002738 & -0.00002448 & 0.005 & -0.002 & -0.001 \\
\hline$R^{2}$ & 0.643 & 0.649 & 0.657 & 0.777 & 0.803 & 0.643 & 0.346 \\
\hline
\end{tabular}

${ }^{a} S$, coefficient for soaking time; $G$, coefficient for germination time; and $F$, coefficient for fermentation time. ${ }^{b}$ Significant at $p<0.05 .{ }^{c}$ Significant at $p<0.01 .{ }^{d}$ Significant at $p<0.001$. ${ }^{e} \mathrm{P} 6$, phytate. Data reported in this table are the measured (fitted) values of the coefficients $b_{0}, b_{i}$, $b_{i i}$, and $b_{i j}$, which are explained in detail in the statistical analysis section.

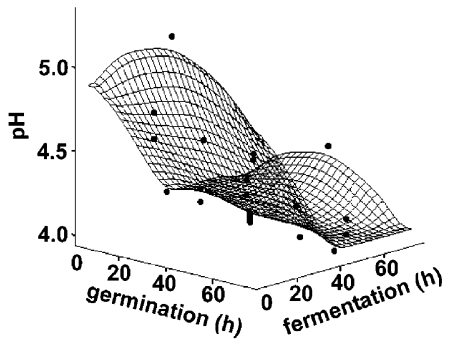

a: Effect on $\mathrm{pH}$

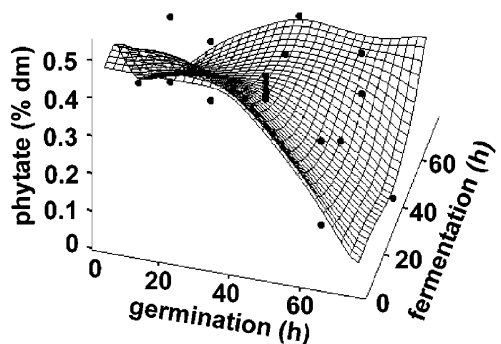

c: Effect on phytate

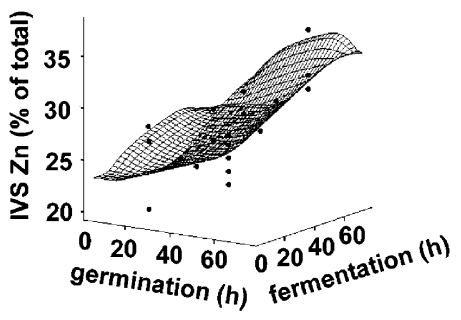

e: Effect on IVS Zn

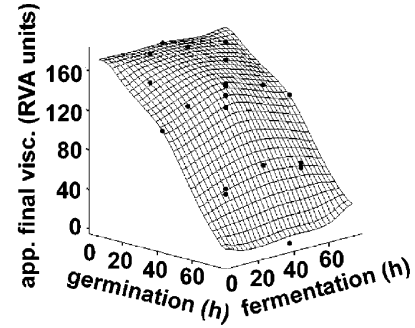

b: Effect on apparent final porridge viscosity

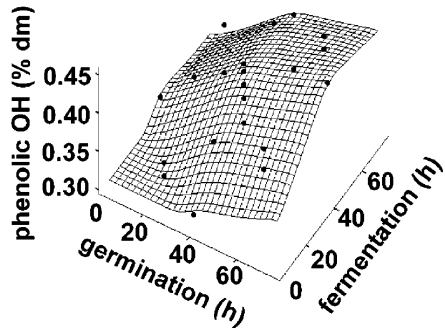

d: Effect on phenolic hydroxyl groups

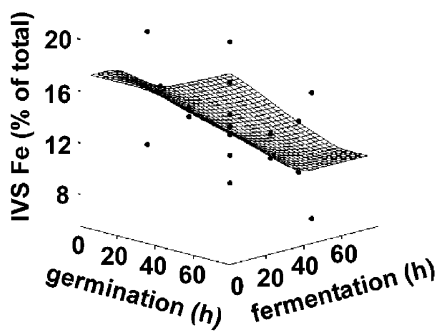

f: Effect on IVS Fe

Figure 1. Response surfaces showing the effects of germination and fermentation periods on (a) pH, (b) final viscosity, (c) phytate, (d) total phenolic reactive hydroxyl groups of sorghum flour porridge, (e) IVS (in vitro soluble) Zn, and (f) IVS Fe in sorghum flour.

$\alpha$-amylase that is activated during the grain sprouting. This result would be of nutritional relevance because it offers the possibility for increasing the concentration of energy and (micro)nutrients in the derived porridge since more dry matter could be incorporated to produce porridge that still has an acceptable "spoonable" consistency.

Impact of Processing Parameters on Phytate and Phenolics Compounds. The phytate values varied among treatments, and the major variation in this component was explained by the model with a $R^{2}=0.643$. The germination and fermentation times significantly affected the phytate content of the sorghum flour. Their linear as well as their interaction terms significantly contributed to phytate response in the model. Moreover, the interaction between soaking and fermentation was also found to be significant. Similar to the findings of Lestienne et al. (33) and Traore et al. (34), soaking alone had no significant effect on the phytate level of the flour. Figure 1c shows the trend in phytate content as a function of germination time, fermentation time, and their mutual interaction. Although rotational effects render it impossible to show this in one picture, both longer germination and/or fermentation times resulted in decrease of phytate concentrations of the flour. The effect of germination 


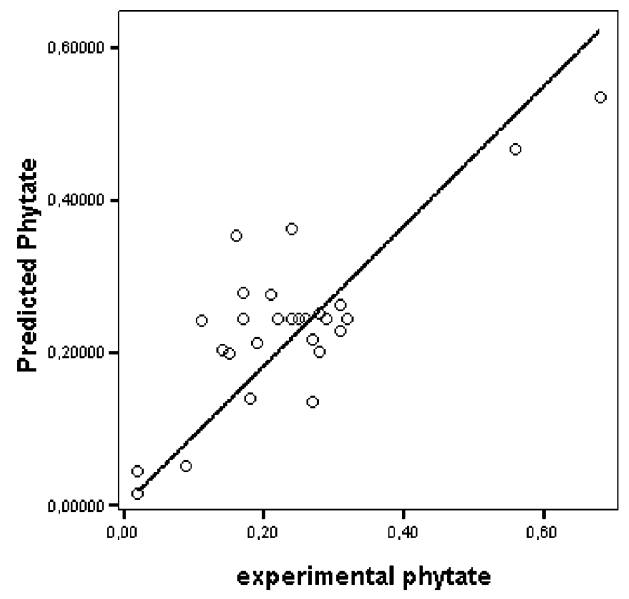

a: Phytate

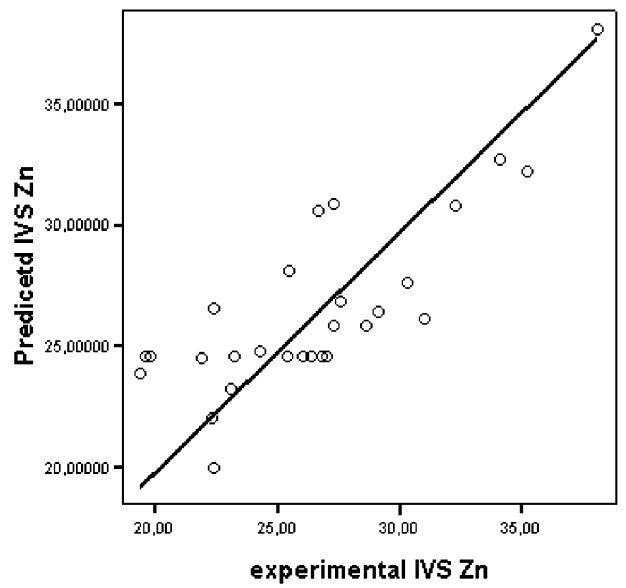

c: IVS Zn

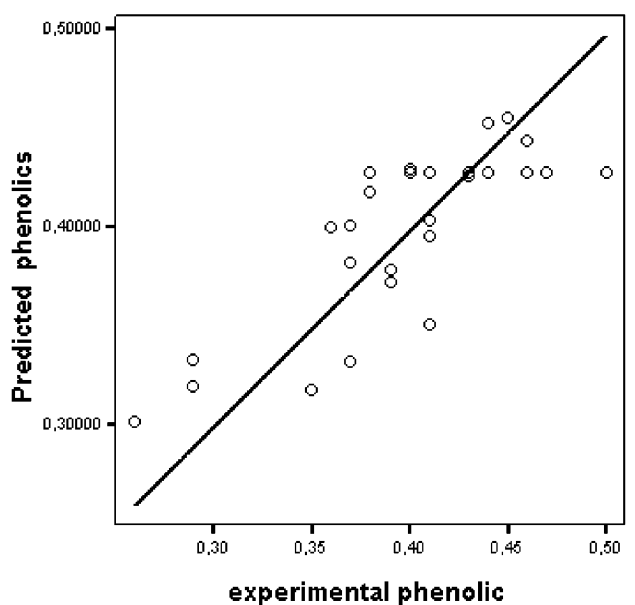

b: Phenolic hydroxyl groups

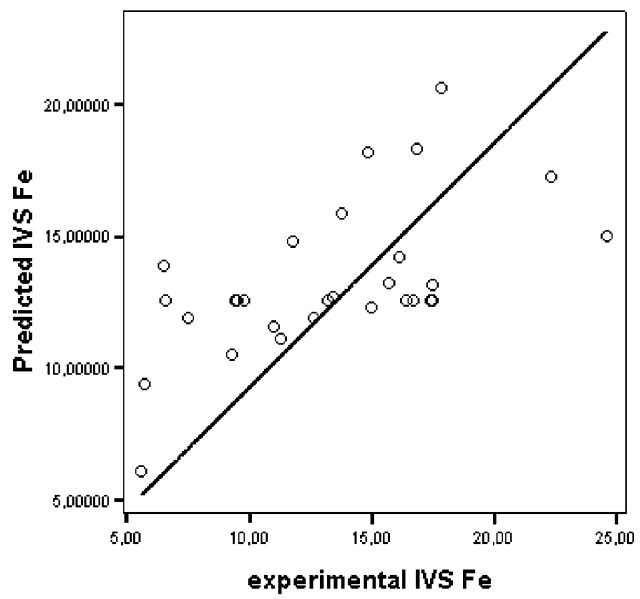

d: IVS Fe

Figure 2. Response trace plots of experimental data against predicted values (a) phytate, (b) total phenolic reactive hydroxyl groups of sorghum flour porridge, (c) IVS (in vitro soluble) Zn, and (d) IVS Fe in sorghum flour.

on phytate was more effective after $20 \mathrm{~h}$ of sprouting. The strongest degradation of phytate occurred after extended germination and fermentation times. Some previous studies (17, 34) demonstrated the decreasing effect of germination and fermentation on phytate content of cereal product, but the mutual interaction of these factors could not be predicted because of the design used in these studies. During the development of the seedling, the degradation of phytate naturally occurs as a means to provide phosphorus for the growth of the young plant. This is achieved through the activation of the endogenous grain phytase during the germination process. In addition, during fermentation of cereal doughs, lactic acid bacteria and yeasts, the major functional microflora, are able to produce phytase and, thereby, reduce the phytate content of food products. In addition, by decreasing the $\mathrm{pH}$ of the dough, fermentation would provide the optimum $\mathrm{pH}$ for phytase activity, which ranges between $\mathrm{pH} 4.5-5$. The interaction of fermentation and $\mathrm{pH}$ decreases, and germination thus certainly causes an activation of endogenous and microbial phytases that degrade phytate.

The total PCs measured by their reactive hydroxyl groups were significantly modified as the result of germination and fermentation. Although the Folin method is not as specific as some HPLC methods, it nevertheless is used presently (35) to quantify (poly)phenolics in general. As we do not yet know which PCs in sorghum are the major complex-forming agents with minerals, we prefer to use this less specific method that includes all components containing reactive phenolic hydroxyl groups. As was shown recently, the Folin method response gives a good measure of the quantity of reactive $\mathrm{OH}$ groups (36). The linear effects of both parameters were found to be significant as were the quadratic terms of soaking and fermentation. At any given germination time in the range between 0 and $72 \mathrm{~h}$, longer fermentation times resulted in increased PC (Figure 1d). The highest values of PC were recorded after long germination and fermentation times. The increase of PC concentration is most likely due to the hydrolysis of condensed phenolics into their lower polymers $(18,19)$, resulting in higher levels of assayable phenolic hydroxyl groups. Reduction of highly condensed PCs in the food would be desirable because these phenolics can interfere with minerals (e.g., Fe) and proteins, rendering them unavailable as nutrients. As reducing the levels of phytate and phenolics in food products is associated with increased availability of divalent minerals (e.g., Fe, Zn, $\mathrm{Ca}$ ), changes in the IVS of $\mathrm{Fe}$ and $\mathrm{Zn}$ are to be expected in the processed infant flour.

Impact of Processing Parameters on IVS of $\mathrm{Zn}$ and Fe. Among the different treatments (see Tables 1 and 2), the highest solubility of $\mathrm{Zn}(38.1 \%)$ was obtained from treatment $22(10 \mathrm{~h}$ of soaking, $72 \mathrm{~h}$ of germination, and $36 \mathrm{~h}$ of fermentation) and the lowest (19.4\%) from treatment 27 (10 h of soaking, $14.6 \mathrm{~h}$ of germination, and $36 \mathrm{~h}$ of fermentation). Values found for the \% IVS Zn (19.4-38.1\%) are of the same order of magnitude 
as those reported by Drago and Valencia (37) for zinc dialyzability $(18-31.59 \%)$ in infant formulas prepared with casein, whey, lactose, vitamin, and corn oil. The germination time was the only processing parameter affecting the percentage of in vitro soluble $\mathrm{Zn}$ (IVS Zn), and its linear and quadratic terms were found to be significant (Table 3). No significant changes took place in the $\mathrm{Zn}$ solubility during the first $24 \mathrm{~h}$ of germination. Thereafter, the $\%$ IVS $\mathrm{Zn}$ increased with the duration of germination, reaching 38\% after $72 \mathrm{~h}$ (Figure 1e). There are significant correlations between \% IVS Zn and phytate and \% IVS Zn and PC content. This correlation is negative for phytate, meaning that the \% IVS $\mathrm{Zn}$ increases when phytate content decreases and is positive for PC. Our observation that changes in phytate and $\mathrm{Zn}$ solubility simultaneously took place (after $24 \mathrm{~h}$ of germination) would support the statement that phytate is the major inhibitor of this mineral $(1,20)$. In absolute terms, the maximum amount of $\mathrm{Zn}$ available to consumers after $72 \mathrm{~h}$ of germination is about $8.5 \mathrm{mg}$ per $\mathrm{kg}$ dry matter. To meet the daily $\mathrm{Zn}$ requirement of $5 \mathrm{mg}$ for infants, they should consume $586 \mathrm{~g}$ of dry matter daily. This is unfeasible because of the limited infant stomach capacity. However, with the lower porridge viscosity achieved as a result of germination, the concentration of dry matter (and nutrients) daily consumed by infants can be increased while maintaining "spoonable" consistency. If the $\mathrm{Zn}$ supply to infants would solely depend on the consumption of sorghum-based porridges, we recommend a fortification with $\mathrm{Zn}$. The type of flour designed in this study would constitute a suitable carrier for $\mathrm{Zn}$, because of its desirable functional properties (sourness, viscosity) and its minimized levels of mineral chelating agents.

Contrary to expectation, the \% IVS Fe tended to decrease as a result of germination and fermentation (Figure 1f), which is in disagreement with a previous finding that germination and fermentation induce increased Fe solubility by degradation of mineral chelating factors (38). Nevertheless, except for the interaction of soaking and fermentation, none of these processing parameters exerted a significant effect on the IVS Fe (Table 3). Overall, only $35 \%$ of the variation in Fe solubility is attributable to the model. Actually, our Fe data show quite a large variation (Figure 2), which is more perceptible at the central point of the design where nine replications were performed (see treatments $1-9$ in Table 2). This variation is mainly due to the relatively low Fe levels, which are close to the level of detection of the method of analysis used, and measurements may also have been disturbed by possible contamination of $\mathrm{Fe}$ from the environment.

Adequacy of the Model. The coefficient of determination $\left(R^{2}\right)$ was calculated to examine the amount of the variation in the response that is explained by the model. A relatively high $R^{2}$ value is a sign that the regression model can be used with confidence for the purpose of the predicting response values (21). In our study, the major variation observed in the responses (except for IVS Fe) is attributable to the model with $64-80 \%$ of the total sum of squares of responses being accounted for by the model. Furthermore, we plotted the experimental data against the predicted values by the model (Figure 2). Overall, except in the case of IVS Fe, the points are scattered favorably around the straight line, which indicates that the model fits the data.

In conclusion, the introduction of germination in the traditional processing of sorghum brought significant improvements in the nutritional quality and functional properties of the infant flour. The application of the RSM revealed the linear effects of the processing parameters as well as their mutual interactions. Germination induces important desirable nutritional modifica- tions, and its effect is enhanced by the fermentation. Such modifications could not be achieved by the current traditional method of producing porridge for infants in many African countries. The low level of antinutritional factors achieved in the flour would make it suitable as a carrier for micronutrient fortification. We therefore recommend further studies of technical and economical opportunities and bottlenecks of incorporation of germination in the production of infant flour.

\section{ACKNOWLEDGMENT}

Elisee Houndelo is gratefully acknowledged for help in laboratory analyses.

\section{LITERATURE CITED}

(1) Frossard, E.; Bucher, M.; Maechler, F.; Mozafar, A.; Hurrell, R. Potential for increasing the content and bioavailability of Fe, $\mathrm{Zn}$ and $\mathrm{Ca}$ in plants for human nutrition. J. Sci. Food Agric. 2000, 80, 861-879.

(2) McCall, K. A.; Huang, C.; Fierke, C. A. Function and mechanism of zinc metalloenzymes. J. Nutr. 2000, 130, 1437-1446.

(3) Brown, K. H.; Peerson, J. M.; Allen, L. H. Effect of zinc supplementation on the growth and serum zinc concentration of prepubertal children: A meta-analysis of randomised controlled trials. Am. J. Clin. Nutr. 2002, 75, 1062-1071.

(4) Sazawal, S.; Black, R. E.; Menon, V. P.; Dinghra, P.; Caulfield, L. E.; Dingra, U.; Bagati, A. Zinc supplementation in infants born small for gestational age reduces mortality: A perspective, randomised, controlled trial. Pediatrics 2001, 108, 1280-1286.

(5) Michaelsen, K. F.; Henrik, F. Complementary feeding: A global perspective. Nutrition 1998, 14, 763-766.

(6) Dossa, R. A. M.; Ategbo, E.-A. D.; De Koning, F. I. H. A.; Van Raaij, J. M. A.; Hautvast, J. G. A. J. Impact of iron supplementation and deworming on growth performance in preschool Beninese children. Eur. J. Clin. Nutr. 2001, 55, 223-228.

(7) Oikeh, S. O.; Menkir, A.; Maziya-Dixon, B.; Welch, R.; Glahn, R. P. Assessment of concentration of iron and zinc and bioavailable iron in grain of early-maturing tropical maize varieties. J. Agric. Food Chem. 2003, 51, 3688-3694.

(8) Rombouts, F. M.; Nout, M. J. R. Microbial fermentation in the production of plant foods. J. Appl. Bacteriol. Symp. Ser. 1995, 79, 108S-117S.

(9) Kayodé, A. P. P.; Adégbidi, A.; Linnemann, A. R.; Nout, M. J. R.; Hounhouigan, D. J. Quality of farmer's varieties of sorghum and derived foods as perceived by consumers in Benin. Ecol. Food Nutr. 2005, 44, 271-294.

(10) Murty, D. S.; Kumar, K. A. Traditional uses of sorghum and millet. In Sorghum and Millets: Chemistry and Technology; Dendy, D. A. V., Ed.; American Association of Cereal Chemists: St. Paul, MN, 1995; pp 185-221.

(11) Nkongolo, K. K.; Nsapato, L. Genetic diversity in Sorghum bicolor (L.) Moench accessions from different ecogeographical regions in Malawi assessed with RAPDs. Genet. Res. Crops Evol. 2003, 50, 149-156.

(12) Uptmoor, R.; Wenzel, W.; Friedt, W.; Donaldson, G.; Ayisi, K.; Ordon, F. Comparative analysis on the genetic relatedness of Sorghum bicolor accessions from southern Africa by RAPDs, AFLPs and SSRs. Theor. Appl. Genet. 2003, 106, 1316-1325.

(13) Motarjemi, Y.; Nout, M. J. R. Food fermentation: A safety and nutritional assessment. Bull. World Health Org. 1996, 74, 553559.

(14) Graf, E. Chemistry and application of phytic acid: an overview. In Phytic Acid: Chemistry and Application; Graf, E., Ed.; Pilatus Press: Minneapolis, MN, 1986; pp 1-21.

(15) Hulse, J. H.; Laing, E. M.; Pearson, O. E. Sorghum and the Millets: Their Composition and Nutritive Value; Academic Press: London, United Kingdom, 1980.

(16) Reddy, N. R.; Pierson, M. D. Reduction in antinutritional and toxic components in plant foods by fermentation. Food Res. Int. 1994, 27, 281-290. 
(17) Svanberg, U.; Lorri, W. Fermentation and nutrient availability. Food Control 1997, 8, 319-328.

(18) Obizoba, I. C.; Atii, J. V. Effect of soaking, sprouting, fermentation and cooking on nutrient composition and some antinutritional factors of sorghum (Guinesia) seeds. Plant Foods Hum. Nutr. 1991, 41, 203-212.

(19) Subramanian, V.; Murty, D. S.; Rao, N. S.; Jambunathan, R. Chemical changes and diastatic activity in grains of sorghum (Sorghum bicolor) cultivars during germination. J. Sci. Food Agric. 1992, 58, 35-41.

(20) Lestienne, I.; Caporiccio, B.; Besancon, P.; Rochette, I.; Trèche, S. Relative contribution of phytates, fibers, and tannins to low iron and zinc in vitro solubility in pearl millet (Pennisetum glaucum) flour and grain fractions. J. Agric. Food Chem. 2005, $53,8342-8348$

(21) Hu, R. Food Product Design. A Computer-Aided Statistical Approach; Technomic Publishing Co.: Lancaster, 1999; p 225.

(22) CARDER. Rapport Agricole 1989-1998, Situation Pluviométrique, Sous-Préfecture de N'dali; Centre d'Action Régionale pour le Développement Rural: Parakou, Benin, 1998.

(23) Giovanni, M. Response surface methodology and product optimization. Food Technol. 1983, 11, 41-45.

(24) Montogomery, D. C. Design and Analysis of Experiments, 5th ed.; John Wiley and Sons: New York, 2001.

(25) Kiers, J. L.; Nout, M. J. R.; Rombouts, F. M. In vitro digestibility of processed and fermented soya bean, cowpea and maize. $J$. Sci. Food Agric. 2000, 80, 1325-1331.

(26) Mestres, C.; Nago, C. M.; Akissoe, N.; Matencio, F. End use quality of some African corn kernels. II Cooking behavior of whole dry-milled maize flour; incidence of storage. J. Agric. Food Chem. 1997, 45, 565-571.

(27) Novozamsky, I.; van Eck, R.; Houba, V. J. G.; van der Lee, J. J. Solubilization of plant tissue with nitric acid-hydrofluoric acid-hydrogen peroxide in a closed system microwave digestor. Commun. Soil Sci. Plant Anal. 1996, 27, 867-875.

(28) Temminghof, E. Soil and Plant Analysis. Part 3. Plant Analysis Procedures; Wageningen University Environmental Sciences: Wageningen, 2000.

(29) Bentsink, L.; Yuan, K.; Koornneef, M.; Vreugdenhil, D. The genetics of phytate and phosphate accumulation in seeds and leaves of Arabidopsis thaliana, using natural variation. Theor. Appl. Genet. 2003, 106, 1234-1243.
(30) Cai, T.; Ejeta, G.; Butler, L. G. Screening for grain polyphenol variants from high-tanin sorghum somaclones. Theor. Appl. Genet. 1995, 90, 211-220.

(31) Singleton, V. L.; Rosii, J. A. Colorimetry of total phenolics with phosphomolybdic-phosphotungstic acid reagents. Am. J. Enol. Vitic. 1965, 16, 144-158.

(32) Nout, M. J. R.; Rombouts, F. M.; Hautvast, G. J. Accelerated natural lactic fermentation of infant food formulations. Food Nutr. Bull. 1989, 11, 65-73.

(33) Lestienne, I.; Icard-Vernière, C.; Mouquet, C.; Picq, C.; Trèche, $\mathrm{S}$. Effects of soaking whole cereal and legume seeds on iron, zinc and phytate contents. Food Chem. 2005, 89, 421-425.

(34) Traore, T.; Mouquet, C.; Icard-Vernière, C.; Traore, A. S.; Trèche, S. Changes in nutrient composition, phytate and cyanide contents and $\alpha$-amylase activity during cereal malting in small production units in Ouagadougou (Burkina Faso). Food Chem. 2005, 88, 105-114.

(35) Dicko, M. H.; Hilhorst, R.; Gruppen, H.; Traore, A.; Laane, C.; Van Berkel, W. J. H.; Voragen, A. G. J. Comparison of content in phenolic compounds, polyphenol oxidase and peroxidase in grains of fifty sorghum cultivars from Burkina Faso. J. Agric. Food Chem. 2002, 50, 3780-3788.

(36) Zanabria Eyzaguirre, R.; Nienaltowska, K.; de Jong, L. E. Q.; Hasenack, B. B. E.; Nout, M. J. R. Effect of food processing of pearl millet (Pennisetum glaucum) IKMP-5 on the level of phenolics, phytate, iron and zinc. J. Sci. Food Agric. In press.

(37) Drago, S. R.; Valencia, M. E. Influence of components of infant formulas on in vitro iron, zinc, and calcium availability. J. Agric. Food Chem. 2004, 52, 3202-3207.

(38) Kayodé, A. P. P.; Hounhouigan, D. J.; Nout, M. J. R. Impact of brewing process operations on phytate, phenolic compounds and in-vitro solubility of iron and zinc in opaque sorghum beer. Food Sci. Technol./LWT In press.

Received for review December 7, 2005. Revised manuscript received April 11, 2006. Accepted April 17, 2006. Financial support provided by Wageningen University through the North-South Interdisciplinary Research and Education Fund (INREF) is gratefully acknowledged. The International Foundation for Science, Stockholm, Sweden, is acknowledged for financial support to A.P.P.K. (Grant IFS E/3736-1).

JF0530493 